\title{
Sustainable development in synergistic relationship with pro- ambient behavior and fair trade
}

\section{El desarrollo sostenible en relación sinérgica con el comportamiento pro ambiental y el comercio justo}

\author{
dx.doi.org/10.17981/ijmsor.01.01.08 \\ Omar Fernando Cortés-Peña \\ Universidad de la Costa \\ ocortes3@cuc.edu.co, Barranquilla, Colombia
}

Research Article - Reception Date: February 28, 2016 - Acceptance Date: March 25, 2016

To reference this paper:

O. F. Cortés-Peña "Sustainable development in synergistic relationship with pro-ambient behavior and fair trade", IJMSOR, vol. 1, no. 1, pp. 54-58, 2016. DOI: dx.doi.org/10.17981/ijmsor.01.01.08

\begin{abstract}
The article comprises a methodological, meta-analytical approach based on different studies, focused on cultural practices of pro-environmental behavior, fair trade and sustainable development, strategically within the framework of a synergistic relationship. Studies are analyzed regarding; Consumer and Environment [1]; Environmental concern and ecological models [2]; Greener life styles [3]; Green lifestyle profiles [4], Sustainability [5]; Structural model of pro-environmental competencies [6]; Perception, knowledge and environmental appreciation [7]; Society and Environment [8]; Pro-environmental behavior [9]; Motivational and cognitive antecedents of pro-environmental behavior ; Behavioral Perspective Model; Smart Consumption; Pro-environmental behavior [10]; Sustainable consumption of public services [11] [12]; Pro-environmental behavior, responsible consumption and sustainable development [13]; Promoting pro-environmental behaviors [14]; Models of self-efficacy and environmental skills [15]; cultural practices of pro-environmental behavior [16]; and the Multidimensional Evaluation Model of Economic Thought [17] among others. The results of the meta-analysis focus on the need to promote programs for eco-friendly lifestyles, development of monitoring and follow up systems for international treaties and national policies in the permanent construction of sustainable development.
\end{abstract}

Keywords - Sustainable Development; Pro-environmental behavior; Fair Trade; Synergy.

\begin{abstract}
Resumen - El artículo comprende una aproximación metodológica de corte meta-analítica a partir de diferentes estudios orientados sobre las prácticas culturales de comportamiento proambiental, el comercio justo y el desarrollo sostenible de forma estratégica bajo el marco de una relación sinérgica. En este sentido, se analizan los estudios sobre Consumidor y Medio Ambiente[1]; Preocupación ambiental y modelos ecológicos [2]; Estilos de vida más verdes" [3]; Perfiles de estilos de vida ecológicos [4], Sostenibilidad [5]; Modelo Estructural de las Competencias Proambientales [6]; Percepción, conocimiento y valoración del ambiente [7]; Sociedad y Medio Ambiente [8]; Comportamiento Proambiental [9]; Antecedentes motivacionales y cognitivos de la conducta proambiental; Behavioral Perspective Model; Consumo Inteligente; Comportamiento Proambiental [10]; Educación para el consumo sostenible [11]; Consumo sustentable de servicios Públicos [11][12]; Comportamiento proambiental, consumo responsable y desarrollo sostenible [13]; Promoción de Conductas Proambientales [14]; Modelos de autoeficacia y habilidades ambientales [15]; Prácticas culturales de comportamiento proambiental [16] y el Modelo de Valoración Multidimensional del Pensamiento Económico [17] entre otros. Los resultados del meta-análisis se orientan a la necesidad de promover programas de promoción de estilos de vida proambiental, unido al desarrollo de sistemas de monitoreo y seguimiento de los tratados internacionales y las políticas de desarrollo nacional en la construcción permanente del desarrollo sostenible.
\end{abstract}

Palabras Clave- Desarrollo Sostenible; Comportamiento Proambiental; Comercio Justo; Sinergia. 


\section{INTRODUCTION}

The contemporary world is facing one of the biggest challenges in history: To Develop cultural practices of environmental conservation, coupled with ensuring quality of life and the social, economic and sustainable development of our peoples. This has been one of the main problems to reflect in the Knowledge Society. Through this, various contributions that integrate academic, social, political and economic scenarios, with the support of various organizations and national and international organizations, have been developed. However, it is one of the main challenges in the development of programs and action projects to advance sustainable development and quality of life, amid the general global crisis. A task that has probably been started too late [13]. The framework of studies on sustainable development and pro-environmental behavior has different approaches and models that have evolved over time. In particular, studies of awareness of the environmental problems of contemporary society at risk [19], together with the correlational analysis between the different central topics of study that establish links between the fields of Environmental Psychology and Social Psychology [20].

From the perspective of studies on population dynamics, there are contributions associated with the multidimensional perspective of population growth and strategic needs of promoting sustainable development models [18]. These studies are associated with the various investigations that allow to demonstrate the lack of real involvement of people in their behavioral consistency against the restrictions and the development of new proenvironmental practices to tackle climate change [5][2][21].

It's important to highlight the approach derived from Positive Psychology for the functional analysis of pro-environmental behavior components [22][23] [24][9], In conjunction with studies to identify the social, educational, economic and behavioral patterns associated with the development of responsible consumption and pro-environmental behavior factors. [25] and [7]. In addition, contributions are identified deriving from the analysis of contextual factors and their impact on environmental performance and environmental awareness [18] and [24], together with the analytical models of attitudinal studies and the importance of the Planned Action Theory towards the effective development of proenvironmental behavior practices [26],[27], [28] and [29].

The importance of the functional analysis of behavior in the study of pro-environmental behavior has been currently highlighted. In this topic, the contributions of different studies are emphasized regarding; Smart Consumption [16], Promoting pro-environmental behaviors [14]; Models of selfefficacy and environmental skills [15]; Public Service and Responsible Consumption [30],[31], [32] no studies have systematically combined delay and probability in a single discounting procedure. Indifference points of hypothetical money rewards that are both delayed and probabilistic were determined. Probabilities were converted into comparable delays according to the $\mathrm{h} / \mathrm{k}$ constant of proportionality determined by Rachlin et al. (1991,[33],[10] and [34]. Similarly, the [35] and [36]in which a specific conceptual framework has been proposed (i.e., the Behavioral Perspective Model, approach under the "Behavioral Perspective Model" is highlighted, allowing a functional integration of pro-environmental behavior and analysis of consumer behavior. In the framework of theoretical models and empirical referents, the Multidimensional Evaluation Model of Economic Thought - VMPE (Spanish acronym) - is presented [17] (see Fig. 1).

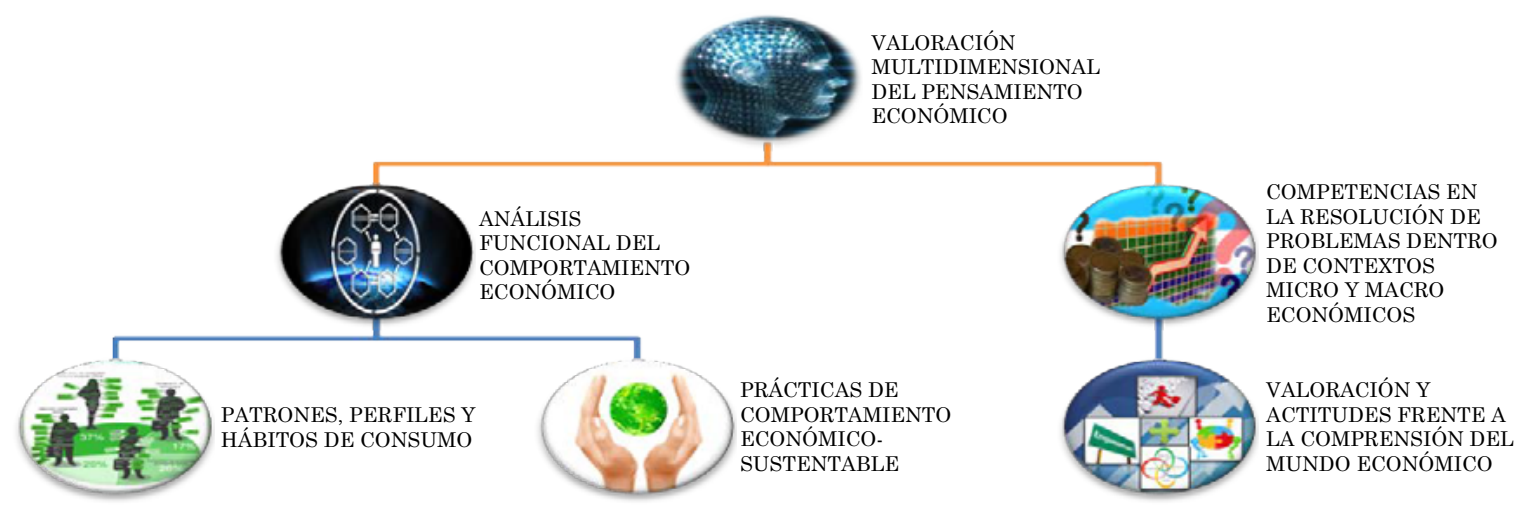

Fig. 1. Economic thought multidimensional Assessment Model Source: [17] 
The VMPE, has been formulated as an alternative derived from the integration between principles of functional behavior analysis, oriented to pattern analysis, profiles and consumption habits, from a relational perspective on the development of sustainable economic behavior practices; Consistent with the assessment of skills in solving micro and macroeconomic problems, regarding the background of the attitudinal assessment that people have in understanding the economic world from a sustainable development perspective.

These elements associated with the study of proenvironmental behavior and their functional relationship to economic behavior and intelligent consumption, become strategic areas of the global crisis' complex problems, experienced on a social, economic and environmental level. Compared to the integrating challenge that provides the horizon of sustainable development. For this purpose, it is necessary to incorporate a relevant topic that corresponds to the development of models of fair trade [37], [38].

Fair Trade can be understood as "a business relationship based on dialogue, transparency and respect, whose main objective is to achieve greater equity in world trade"[39] Its strategic goals involve the opportunity for producers and marginal workers to overcome their vulnerability and access to economic models of fair appraisal, with greater autonomy in their production processes and marketing, in turn generating a model of economic development and social solidarity, equitable and inclusive. In this regard, the functional link between the pro environmental behavior, responsible and intelligent consumption, and fair trade, are a synergistic stage in the construction of sustainable development, as illustrated in Fig. 2.

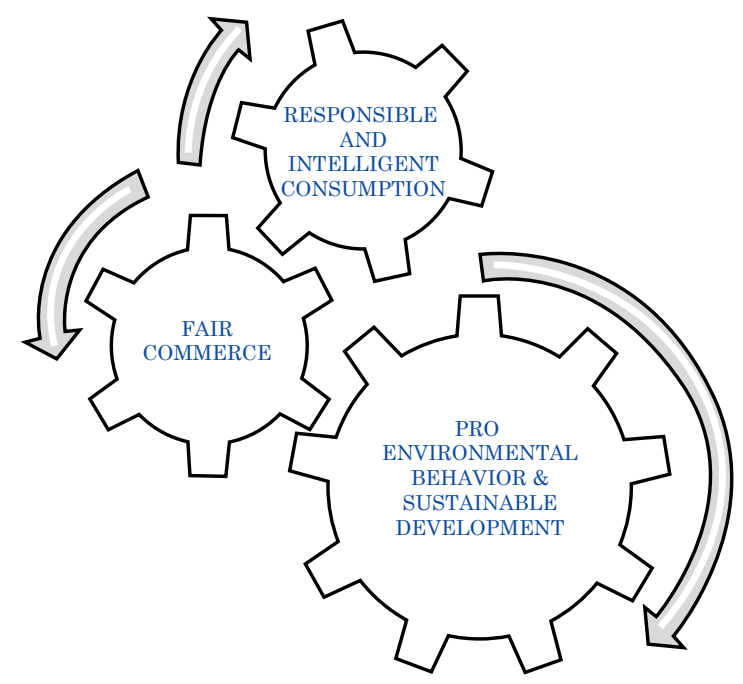

Fig. 2. Synergetic Relationship and Intelligent Responsible Consumption - Fair Trade - Pro-environmental behavior and Sustainable Development Source: [13]
This functional integration, additionally requires the development of public policies based on the integration of different knowledge, research, projects, programs, campaigns and actions that not only remain in the stage of scientific and academic audiences, but especially impact vigorously the different strategies and modalities for Innovation and Social Appropriation of Knowledge as input for the transformation and the integral development of communities, actively linking the state, business, university and society in an interdependent relational model; as illustrated in Fig. 3.

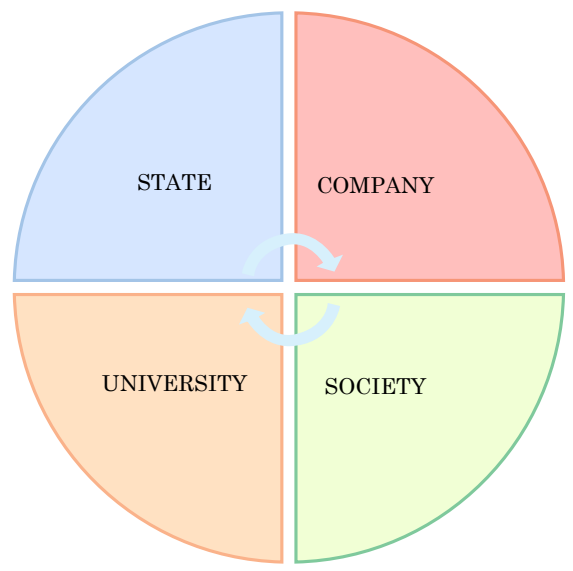

Fig. 3. Social Appropriation of Knowledge: Interdependent Relationship State - Company - University - Society Source: [11]

\section{Discussion}

The formulation of State policies and the development of effective practices for pro-environmental conservation, sustainable consumption and fair trade requires strengthening intervention towards transforming lifestyles and improving pro-environmental and sustainable cultural practices, starting with the daily household. The role of higher education is vital, proposals like [3] on development "greener lifestyles" as well as input from [4] towards the development of consistent ecological profiles, present in contemporary lifestyles [40]-[50].

In this sense, campaigns and, environmental conservation and sustainable consumption programs should be broader, towards the development of policies that establish recognition and control systems to encourage pro-environmental cultural practices and mitigate the irrational and indiscriminate use of natural resources, analyzing the synergistic relationship between sustainable development, cultural practices of pro-environmental behavior and fair trade, from functional and integrative perspectives as proposed in the Multidimensional Evaluation Model of Economic Thought - VMPE [17]. 
Thus, a priority invitation is presented to all members of the scientific community, to integrate their knowledge in promoting scenarios of permanent reflection on the complexity of social, economic, cultural, political and environmental reality, and develop interdisciplinary campaigns aimed at proenvironmental evaluation, responsible consumption, quality of life and sustainable development, supported by the ongoing strengthening of the functional relationships between state, business, university and society, to consolidate the processes of innovation and social appropriation of knowledge-oriented Sustainable Community Development.

\section{III.Acknowledgements}

The author expresses his gratitude to the Universidad de la Costa - CUC for their continued institutional support and in particular to the Research Group Cultura, Educación y Sociedad, as well as Drs. Tito Crissien, Henry Maury, Gloria Moreno, José Lozano and Ketty Herrera, for each and every one of their valuable contributions in the development of this article.

\section{REFERENCES}

[1] National Research Council, Environmentally Significant Consumption. Washington, D.C.: National Academies Press, 1997.

[2] J. M. Berenguer and J. A. Corraliza, "Preocupación ambiental y comportamientos ecológicos," Psicothema, vol. 12, no. Número 3, pp. 325-329, 2000.

[3] Karl W. Brand, "Conciencia y Comportamiento Medioambientales: Estilos de Vida más' Verdes,” Michael Redcliff y Graham Woodgate, Sociol. del Medioambiente Una Perspect. Int., pp. 205-222, 1997.

[4] O. Iwata, "Coping Style And Three Psychological Measures Associated With Environmentally Responsible Behavior," Soc. Behav. Personal. an Int. J., vol. 30, no. 7, pp. 661-669, Jan. 2002.

[5] King Roy, Managing for Sustainability. Publisher Scitech Educational Ltd, 2000.

[6] V. Corral-Verdugo, "A Structural Model of Proenvironmental Competency," Environ. Behav., vol. 34, no. 4, pp. 531-549, Jul. 2002.

[7] L. Rizo López, F. M. Gutiérrez C, and H. Granada E, "Percepción, Conocimiento Y Valoración Del Ambiente Físico Y Social De La Universidad Del Valle Sede Meléndez En Un Grupo De Estudiantes Y Su Influencia En El Comportamiento Ecológico Responsable," Psicol. Desde el Caribe, vol. 0, no. 0, 2011.

[8] C. Oltra Algado, "Sociedad y Medio Ambiente. Ciudadanos y Científicos ante el Proceso de la Reforma Medioambiental de la Sociedad," Universidad de Barcelona , 2006.

[9] J. Martínez-Soto, "Comportamiento proambiental. Una aproximación al estudio del desarrollo sustentable con énfasis en el comportamiento persona-ambiente."

[10] R. M. R. Turaga, R. B. Howarth, and M. E. Borsuk, "Pro-environmental behavior," Ann. N. Y. Acad. Sci.,vol. 1185, no. 1, pp. 211-224, Jan. 2010.

[11] O. F. Cortés Peña, "De las palabras a las acciones: Aplicaciones del Behavioral Perspective Model (BPM) al Consumo Responsable," in Primer congreso en Psicología del Conusmidor., 2008.
[12] O. F. Cortés-Peña, "Actitudes proambientales y el consumo sustentable de los servicios públicos domiciliarios de agua y energía eléctrica en la ciudad de barranquilla," Universidad del Norte, 2014.

[13] O. F. Cortés-Peña, "Comportamiento proambiental y pensamiento económico en la construcción del desarrollo sostenible*," Cult. Educ. Y Soc., vol. 2, no. 1, pp. 43-56, 2011.

[14] K. Herrera and O. F. Cortés, "Programa cognitivo conductual de promoción de conductas proambientales en jóvenes universitarios." Universidad de la Costa, Barranquilla, 2012.

[15] J. R. Palacios Delgado and J. M. Bustos Aguayo, "Modelo de autoeficacia y habilidades ambientales como predictores de la intención y disposición proambiental en jóvenes," Rev. Intercont. Psicol. y Educ. , vol. 14, no. 2, pp. 143-163, 2012.

[16] M. Sandoval, C. Caycedo, and W. López López, "El Consumo Inteligente Más Alla Del Libre Albedrío: Una Visión Desde El Autocontrol," FOCAD, 2008.

[17] O. F. Cortés Peña, R. Abello Llanos, M. Denegri Coria, and A. M. Pérez-Acosta, "Multidimensional Model of Assessment of Economic Thinking in College Students," Procedia - Soc. Behav. Sci., vol. 191, pp. 1623-1628, Jun. 2015.

[18] B. on E. C. and S. Committee on the Human Dimensions of Glo, National Research Council, Environmentally Significant Consumption, National R. Washington, D.C., D.C.: National Academies Press, 1997.

[19] R. Franco Vargas, "La sostenibilidad: una postura autocrítica de la sociedad industrial," Investig. Desarro., vol. 13 , no. 1,2005 .

[20] R. W. Kates, "Population and Consumption. Environment. Reprinted with permission of the Helen Dwight Reid Educational Foundation," Enviroments, pp. 10-19, 2000.

[21] C. C. Secadas, "Escala para la evaluación de las actitudes pro-ambientales (EAPA) de alumnos universitarios," Rev. Complut. Educ., vol. 6, no. 2, pp. 253-278, 1995.

[22] S. A. Wagner, Understanding green consumer behaviour: a qualitative cognitive approach. Routledge, 1997.

[23] V. C. Verdugo, M. F. Armenta, D. G. Lomelí, D. Baldenegro, L. Contre R A S, A. N. D. R. Ley, L. Lu-Zanía, and L. Sánch, "Percepción de riesgos, conducta proambiental y variables demográficas en una comunidad de Sonora, México *” Región y Soc., vol. xv, pp. 49-72, 2003.

[24] A. González López, "La Preocupación Por La Calidad Del Medio Ambiente. Un Modelo Cognitivo Sobre La Conducta Ecológica," UNIVERSIDAD COMPLUTENSE DE MADRID, 2002.

[25] S. B. Follows and D. Jobber, "Environmentally responsable purchase behaviour: a test of a consumer model," 2013. Doi: http://dx.doi.org/10.1108/03090560010322009

[26] M. A. Fishbein and I. Ajzen, "Belief, Attitude, Intention, Behavior: An Introduction to Theory and Research," vol. 27, no. 1,1975 .

[27] S. C. Hayes, D. Barnes-Holmes, and B. Roche, Eds., Relational Frame Theory. Boston: Kluwer Academic Publishers, 2002.

[28] V. Corral-Verdugo and J. Q. Pinheiro, "Condições para o estudo do comportamento pró-ambiental," vol. 4, no. 1, pp. 7-22, 1999.

[29] M. Alzate, J. M. Sabucedo, M. Durán, and W. López, "Emociones y comportamiento pro-ambiental," Rev. Latinoam. Psicol., vol. 39, no. 2, pp. 287-296, 2007.

[30] C. García Lirios, "¿Cuáles son los determinantes psicológicos y situacionales de un uso sustentable de agua en la Zona Metropolitana del Valle de México?,” REME, vol. 8 , no. 19 , p. $4,2005$.

[31] F. Van Overwalle and B. Timmermans, "Discounting and the role of the relation between causes," Eur. J. Soc. Psychol., vol. 35, no. 2, pp. 199-223, Mar. 2005. 
[32] R. Yi, X. de la Piedad, and W. K. Bickel, "The combined effects of delay and probability in discounting," Behav. Processes, vol. 73, no. 2, pp. 149-155, 2006.

[33] M. Jiménez and R. Lafuente, "La conciencia ambiental: Qué es y cómo medirla," 2007.

[34] M. Sandoval Escobar, "Comportamiento sustentable y educación ambiental: una visión desde las prácticas culturales Sustainable behavior and environmental education: a view from cultural practices," Rev. Latinoam. Psicol., vol. 44, no. 1, pp. 181-196, 2012

[35] G. R. Foxall, "A Behaviourist Perspective on Purchase and Consumption," E - Eur. Adv. Consum. Res. Vol. 1, 1993.

[36] G. R. Foxall, J. O. Castro, V. K. James, M. M. Yani-deSoriano, and V. Sigurdsson, "Consumer Behavior Analysis and Social Marketing: The Case of Environmental Conservation,” Behav. Soc. Issues, vol. 15, no. 1, p. 101, Mar. 2006.

[37] Z. O'leary, The Essential Guide To Doing Research. London: SAGE Publications Inc, 2004

[38] V. Corral-Verdugo, G. Carrus, M. Bonnes, G. Moser, and J. B. P. Sinha, "Environmental Beliefs and Endorsement of Sustainable Development Principles in Water Conservation: Toward a New Human Interdependence Paradigm Scale," Environ. Behav., vol. 40, no. 5, pp. 703-725, Jan. 2008.

[39] A. García Chiang, "El comercio justo: ¿una alternativa de desarrollo local?," Polis, vol. 7, no. 1, pp. 105-140, 2011.

[40] A. P. Cortés Vásquez, "Sistema de Aprendizaje de Patrones de Navegación Web Mediante Gramáticas Probabilísticas de Hipertexto," INGE CUC, vol. 11, no. 1, pp. 72-78, 2015. Doi: 10.17981/ingecuc.11.1.2015.07

[41] M. Á. Gómez Borja, "Efectos del conocimiento y la similitud entre alternativas sobre las estrategias y la calidad de la decisión en el consumidor: Un enfoque de proceso," 2000 .
[42] C. E. Gómez Montoya, C. A. Candela Uribe, and L. E. Sepúlveda Rodríguez, "Seguridad en la configuración del servidor web Apache," INGE CUC, vol. 9, no. 2, pp. $31-38,2013$.

[43] J. Marcos, B. Aguayo, M. F. Herrera, and P. A. Palos, "Predicción de la conservación de agua a partir de factores socio-cognitivos," Medio Ambient. Comport. Hum, vol. 5, no. 1y2, pp. 53-70, 2004.

[44] A. Cama Pinto, E. De la Hoz Franco, and D. Cama Pinto, "Las redes de sensores inalámbricos y el internet de las cosas," INGE CUC, vol. 8, no. 1, pp. 163-172, 2012.

[45] Belkis Cartay A., "Consideraciones en torno a los conceptos de calidad de vida y calidad ambiental," Fermentum. Rev. Venez. Sociol. y Antropol., vol. 14, no. 41, p.491-502, 2004 .

[46] M. Moreno, J. A. Corraliza, and J. P. Ruiz, "Escala de actitudes ambientales hacia problemas específicos," Psicothema, vol. 17, no. 3, pp. 502-508, 2005.

[47] A. Gómez Cabrera and A. R. Orozco Ovalle, "Simulación digital como herramienta para la gestión del conocimiento en la construcción de edificaciones en concreto," INGE CUC, vol. 10, no. 1, pp. 75-82, 2014

[48] G. Ochoa, T. Tin, and J. Hoffman, Climate: The Force That Shapes Our World and the Future of Life on Earth. 2005.

[49] J. J. Cabello Eras et al., "Comparative study of the urban quality of life in Cuban first-level cities from an objective dimension," Environment, Development and Sustainability, vol. 16, no. 1, pp. 195-215, Feb. 2014. doi:10.1007/s10668-013-9470-0

[50] L. Fernández Manzanal, Rosario Rodríguez Barreiro and J. Carrasquer Zamora, "El conocimiento de las actitudes ambientales: una buena base para mejorar las conductas hacia el medio ambiente," in III Jornadas De Educación Ambiental De La Comunidad Autónoma De Aragón, 2006, pp. 1-7. 